\title{
DAMPAK COVID-19 TERHADAP PEREKONOMIAN MASYARAKAT DAN PEMBANGUNAN DESA
}

\author{
Sarip, Aip Syarifudin dan Abdul Muaz \\ Universitas Muhammadiyah Cirebon \\ Email: sarip@umc.ac.id,aip.syarifudin@umc.ac.id \\ dan muaz@umc.ac.id
}

\begin{abstract}
The article aims to examine the impact of Covid-19 on the community's economy and village development. The village always gets help, leads to circumstances or gives birth to the village losing its identity. The loss of the village's identity is proven by the existence of whatever is required by the government in its transmission, it must get rewards in the form of material. The basic problem is how to fulfill the economy as a basic human need in order to carry out activities in the world in order to fulfill welfare, safety. The relationship between village democracy with the direction of the economy and village development which is an inseparable unit. Democracy influences the handling of Covid-19, is a real test of the results of village democracy in realizing the economy and development. The research is intended to understand the impact of outbreaks on the village economy, rural development that is sweeping the world. The views of the village community have experienced a crisis of confidence, due to the role played by the central and regional governments that do not pay attention to the village as an independent government losing its identity. For the sake of the realization of a village democracy in the field of economy and development, ideally building the character of a society free from dependency.
\end{abstract}

Keywords: Covid-19, Economy, Development, and Democracy.

\begin{abstract}
Abstrak
Artikel bertujuan mengkaji dampak Covid-19 terhadap perekonomian masyarakat dan pembangunan desa. Desa selalu mendapatkan bantuan, mengarah pada keadaan atau melahirkan desa kehilangan identitasnya. Hilangnya identitas desa terbukti dengan adanya apapun yang diharuskan oleh pemerintah dalam penularannya, harus mendapatkan imbalan berupa materi. Persoalan mendasar bagaimana pemenuhan perekonomian sebagai kebutuhan dasar manusia dalam rangka menjalankan aktivitas di dunia guna memenuhi kesejahteraan, keselamatan. Hubungan antara demokrasi desa dengan arah perekonomian dan pembangunan desa yang merupakan satu kesatuan yang tidak dapat dipisahkan. Demokrasi mempengaruhi penanggulangan Covid-19, merupakan ujian nyata hasil demokrasi desa dalam mewujudkan perekonomian dan pembangunan. Penelitian dimaksudkan untuk memahami dampak wabah terhadap perekonomian desa, pembangunan desa yang sedang melanda dunia. Pandangan masyarakar desa telah mengalami krisis kepercayaan, akibat peran yang dimainkan pemerintah pusat dan daerah yang kurang memperhatikan desa sebagai pemerintahan mandiri kehilangan identitasnya. Demi terwujudnya suatu demokrasi desa di bidang perekonomian dan pembangunan, idealnya membangun karakter masyarakat yang bebas dari ketergantungan.
\end{abstract}

Kata Kunci: Covid-19, Perekonomian, Pembangunan, dan Demokrasi. 


\section{PENDAHULUAN}

Lahinya Covid-19 telah merubah perekonomian dunia, termasuk Indonesia dibuktikan adanya pengalihan-pengalihan anggaran dalam rangka penanganya, termasuk di desa-desa. Penamanaa 2019nCoV disematkan World Health Organization (WHO) untuk coronavirus disease that was discoverd in 2019 pada tanggal 11 Februari 2020, dengan sebutan Covid-19 (Yuliana, 2020). Memiliki dampak yang sangat luar biasa di seluruh dunia tidak ketinggalan juga dengan desadesa yang ada di Indonesia. Desa-sesa terpengaruh terutama dalam bidang ekonomi dan pembangunan yang selama ini banyak mengandalkan bantuan dari pusat.

UU No. 6 Tahun 2014 tentang Desa, memiliki tujuan menbangun desa secara sistematis, konsisten dan berkelanjutan dengan fasilitasi, supervisi dan pendampingan (Amanulloh, 2015). Pembangunan desa dari pinggiran memfokuskan diri pada bidang perekonomian dan kurang memperhatikan demokrasi desa yang kerap kali mendapatkan sorotan secara hukum dan politik. Pemerintah pusat kurang memperhatikan demokrasi desa dan lebih fokus pada perekonomian (Wulandari, 2017). Perekonomian dan pembangunan pemerintahan tersebut tidak dapat lepas dari perkembangan dinamika hukum dan politik yang terjadi ditingkatan nasional. Pemerintah menjadikan perekonomian dan pembangunan semakin bergantung pada kebijakan-kebijakan pusat dan menghilangkan karakter desa sendiri.

Perekonomian dan pembangunan desa pada dasarnya diawali dengan adanya demokrasi desa atau yang sering dikatakan sebagai pemilihan kepala desa. Demokrasi desa sebetulnya tidak semata-mata memperebutkan kekuasaan untuk mendapatkan dukungan suara masyarakat, menyangkut harga diri, dan gengsi bagi calon kepala desa (Yuningsih \& Subekti, 2016). Pemilihan kepala desa tidak kalah panasnya, dibandingkan dengan masalah pemilihan di ditingkatan nasional. Pemilihan kepala desa bagi masyarakat desa, dinilai lebih bergengsi dibandingkan dengan pemilihan di tingkat daerah maupun nasional. Pemilihan kepala desa membuka ruang-ruang untuk membangun perekonomi yang pendanaanya berasal dari pusat. Datangnya wabah Covid-19, menjadikan beberapa pembangunan ekonomi dan desa kelihatannya tidak berjalan secara maksimal. Persoalan mendasar tentang ekonomi yakni bagaimana pemenuhan kebutuhan dasar manusia dalam rangka menjalankan aktivitas di dunia guna memenuhi kesejahteraan, keselamatan, dan kemakmuran hidup bagi orang banyak (Haerisma, 2019).

Adanya hubungan antara demokrasi desa dengan arah perekonomian dan pembangunan desa yang merupakan satu kesatuan yang tidak dapat dipisahkan. Hasil demokrasi mempengaruhi penanggulangan Covid-19 yang merupakan ujian nyata hasil demokrasi desa dalam mewujudkan perekonomian dan pembangunan yang harus dilaksanakan sebagaimana visi dan misinya yang harus sejalan dengan Pancasila (Sarip \& Wahid, 2018). Maka permasalahan yakni (1) Bagaimana peran desa dalam bidang ekonomi dan pembangunan pada saat terjadinya wabah Covid-19; (2) Seperti apakah paran pemerintah pusat yang ideal dalam bidang ekonomi dan pembangunan bagi masyarakat desa yang berbeda-beda.

\section{LITERATURE REVIEW}

Penelitian tentang pemikiran dampak Covid-19 terhadap perekonomi dan pembangunan desa, terlihat sangat sederhana dengan alasan yang dibiacarakan desa. Padahal banyak sekali penelitian yang sudah membahas dampak Covid-19 terhadap perekonomian dan pembangunan yang cakupannya sangat luas. Meskipun demikian, nampaknya belum banyak penelitian yang secara spesifik membahasnya, yang mencoba memadukan antara Covid-19, perekonomian, 
pembangunan desa. Berikut beberapa karya yang terdokumentasikan terkait permasalahan yang dikaji. Desa dipandang sebagai suatu pemerintahan terendah yang mempunyai identitas, entitas, memiliki batas-batas wilayah tertentu dan memiliki kewenangan untuk mengatur dan mengurus kepentingan masyarakat setempat, berdasarkan asal usul dan adat istiadat setempat yang diakui dan dihormati (Purnamasari, 2019). Pemberitaan dari Meneteri Keuangan berkenaan dengan pandemic Covid-19 terhadap ekonomi Indonesia(Puspasari, 2020).

Keberadaan desa lebih dipahami sebagai daerah kesatuan hukum dimana memiliki kekuasaan untuk mengurus dan mengelola pemerintahan secara mandiri (Kushandajani \& Kushandajani, 2017). Penelitian Prijono Tjiptoherjanto dan Yumiko M. Prijono tahun 1983 yang melakukan penelitian tentang desa di Jawa terkait dengan dominasi elite desa yang berorientasi pada pemerintah supradesa. Sejalan dengan penelitian Neneng Yani Yuningsih dan Valina Singka Subekti menyatakan Pemilihan Kepala Desa (Pilkades) tidak dapat dilepaskan dari perkembangan nilai-nilai modern dan ekonomi masuk ke desa sebagaimana hasil penelitian tahun 2008-2013 di Jawa Barat (Yuningsih \& Subekti, 2016).

Hal berbeda dilakukan oleh Endrik Hidayat, Budi Prasetiyo, dan Setya Yuana di tahun 2016, bahwa politik oligarki dapat diruntuhkan dengan kekuatan politik patronklien (Hidayat et al., 2019). Selain unjuk kekuatan ekonomi yang berifat oligarki dalam Pilkades juga menjadi ajang berkenaan sumber nonmaterial yang digunakan sebagai sumber kekuatan. Kemudian terakhir berkenaan dengan info terhadap pembangunan dunia internasional akibat adanya pandemik dalang ruang lingkup internasional (Lisbet, 2020). Maka, penelitian akan mencoba mengambil cakupan yang belum banyak dilakukan pembahasan yang berkenaan dengan desa akibat adanya wabah Covid-19 dibidang perekonomian dan pembangunannya.

\section{METODE PENELITIAN}

Penelitian dimaksudkan untuk memahami dampak Covid-19 terhadap perekonomian desa, pembangunan desa ditengah-tengan wabah yang sedang melanda dunia. Peneliti mencoba menggambarkan apa yang dipahami dan digambarkan subyek penelitian. Kemudian pendekatan kualitatif dipilih dengan metode deskriptif dan jenis penelitian ini menggunakan penelitian kepustakaan (library research) yakni penelitian dilaksanakan dengan cara pencarian literatur (kepustakaan) baik berupa buku, catatan, maupun laporan hasil penelitian dari penelitian sebelumnya. Data tambahan didapatkan dari pengamatanpengamatan selama adanya wabah tahun 2020 di desa terutama yang menyangkut perekonomian dan pembangunan desa.

Teknik pengumpulkan data yang dilakukan penulis dengan mengidentifikasi tema atau wacana dari buku-buku, makalah atau artikel, majalah, jurnal dari hasil penelitian terdahulu, web (internet), atau juga data yang diambil dari informasi lainnya yang berhubungan dengan tema penelitian ini untuk mencari hal-hal atau variable yang berupa catatan, transkip, buku, surat kabar dan sebagainya yang berkaitan dengan fokus penelitian. Adapun langkah penelitian sebagai berikut: mengumpulkan data-data yang ada baik dan menganalisa data-data melalui buku-buku teks, dokumen lain, dan sebagainya. Setelah mendapatkan beberapa data, maka data kemudian dianalisis untuk mendapatkan kesimpulan, cara analisa data sebagai berikut: Analisis Deskriptif (Descriptif Analysis), peneliti melakukan pemetaan tempat terhadap data-data yang akan dicari. Analisis isi (Content Analysis), menganalisa lebih dalam berkaitan buku, majalah, jurnal, penelitian bukan hanya isi pada data tersebut melainkan peneliti akan mengungkapkan latar belakang, waktu, aspek, kemudian mengungkapkan 
argumentasi sesuai dengan penelitian (Haerisma, 2019).

Peneliti melakukan analisis data secara induktif, dimulai dari lapangan atau fakta empiris dengan cara terjun ke lapangan, mempelajari fenomena atau fakta empiris dengan cara terjun ke lapangan, mempelajari fenomena yang ada di lapangan. Analisis data dalam penelitian kualitatif dilakukan secara bersamaan dengan cara proses pengumpulan data. Adapun tahapan analisis data sebagai berikut: Reduksi Data, Penyajian Data, peneliti memberikan kesimpulan tiap-tiap penelitian yang berkenaan dengan perekonomian dan pembangunan desa di era Covid-19. Verifikasi juga dilakukan setelah data disajikan untuk ditarik dalam bentuk simpulan.

\section{KONSEP DASAR \\ Pengertian Covid-19}

Virus Corona menyebabkan penyakit flu biasa sampai penyakit yang lebih parah seperti Sindrom Pernafasan Timur Tengah (MERS-CoV) dan Sindrom Pernafasan Akut Parah (SARS-CoV). Virus Corona adalah zoonotic yang artinya ditularkan antara hewan dan manusia. Berdasarkan Kementerian Kesehatan Indonesia, perkembangan kasus Covid-19 di Wuhan berawal pada tanggal 30 Desember 2019 dimana Wuhan Municipal Health Committee mengeluarkan pernyataan "urgent notice on the treatment of pneumonia of unknown cause" (Hanoatubun, 2020). Penyebaran virus Corona ini sangat cepat bahkan sampai ke lintas negara. Sampai saat ini terdapat 188 negara yang mengkorfirmasi terkena virus Corona. Penyebaran virus Corona yang telah meluas ke berbagai belahan dunia membawa dampak pada perekonomian Indonsia, baik dari sisi perdagangan, investasi dan pariwisata. Keadaan dunia saat sekarang apabila dilihat dari pemaknaan totem, telah mengalami pengalihan sosok totem tersebut.
Apa yang dinamakan sebagai totem sendiri rupanya bukan hanya berlaku pada nilai-nilai keagamaan saja, bahkan sekelas negara memiliki totem masing-masing sebagai bentuk kesakralan bagi masyarakatnya. Penggunaan kata totem negara sendiri memiliki dasar pemikiran tersendiri, yakni dengan mengacu pada pengertian negara yang apabila ditarik pada sudut pandang ini, negara merupakan organisasi bangsa. Totem 2019-nCoV disematkan World Health Organization (WHO) untuk coronavirus disease that was discoverd in 2019 pada tanggal 11 Februari 2020, di Indonesia lebih popular dengan sebutan Covid-19 (Yuliana, 2020). Keberadaannya, memaksa pemerintah mengeluarkan kebijakan yang berkenaan dengan keadaan darurat, sering dikenal dengan sebutan Peraturan Pemerintah Pengganti Undang-Undang (Perpu) (Hsb, 2017).

\section{Pengertian Ekonomi dan Pembangunan Desa}

Ekonomi adalah salah satu faktor penting dalam kehidupan manusia. Dapat dipastikan dalam keseharian kehidupan manusia selalu bersinggungan dengan kebutuhan ekonomi (Astutiningsih \& Sari, 2017). Keberadaan ekonomi dapat memberikan kesempatan bagi manusia untuk memenuhi kebutuhan hidupnya seperti makanan, minuman, berpakaian, tempat tinggal, dan lain sebagainya. Pentingnya ekonomi dalam kehidupan manusia tersebut menuntut negara untuk mengatur kebijakan tentang perekonomian dan menjamin perekonomian warga negara khususnya di Indonesia yang memproklamirkan diri sebagai negara kesejahteraan (welfare staat). Dalam konsep negara kesejahteraan adalah negara berhak untuk ikut campur dalam segala aspek kehidupan warga negaranya termasuk dalam bidang ekonomi. Selain daripada itu, pertumbuhan ekonomi juga merupakan faktor yang mendukung pembangunan nasional dalam sebuah negara. Pertumbuhan 
ekonomi yang baik akan dapat meningkatkan pembangunan nasional.

Pembangunan sendiri merupakan proses atau cara membangun atau menjadikan sesuatu agar lebih berwujud. Desa menurut UU No. 6 tahun 2014 adalah kesatuan masyarakat hukum yang memiliki batas wilayah yang berwenang untuk mengatur dan mengurus urusan pemerintahan, kepentingan masyarakat setempat berdasarkan prakarsa masyarakat, hak asal usul, dan atau hak tradisional yang diakui dan dihormati dalam sistem pemerintahan Negara Kesatuan Republik Indonesia. Untuk mendapatkan dukungan dan partisipasi yang kuat dari masyarakat terhadap pembangunan desa, maka masyarakat harus dilibatkan dalam proses pengambilan keputusan termasuk pada tahapan perencanaan pembangunan desa. Dengan demikian diharapkan akan timbul suatu rasa tanggung jawab bersama seluruh masyarakat desa terhadap pembangunan di desanya.

Konsep the king can not do wrong menjadi tumpuan bagi paraturan darurat, kebijakan tidak dapat disalahkan selama atas nama negara, memiliki itikad baik, atau sering dikaitkan dengan hak prerogratif presiden (Sarip, 2018a). Kebijakan pemerintah Indonesia dinilai kurang dapat mempertimbangkan suara rakyat, menjadikan konsep the king can not do wrong menguat ditengah-tengah totem 2019-nCoV dan dapat melahirkan people power. Garuda sebagai totem negara Indonesia yang mengemban nilai Pancasila, kakinya yang melindungi Bhinneka Tunggal Ika, mengalami pengesampingan dengan adanya totem baru yang sedang menjadi primadona global. Desa sebagai kesatuan pemerintahan terkecil dalam Negara Indonesia memiliki tugas dibidang perekonomian dan pembangunan desa.
PEMBAHASAN DAN DISKUSI

\section{Peran Demokrasi Desa Pada Perekonomian dan Pembangunan Desa di Era Covid-19}

Tentang keberadaan organsisasi desa sendiri hanya pada dasarnya tidak berdiri sendiri atau beriringan dengan pemerintah pusat. Di dalam demokrasi desa Kebijakan tentang apa yang menjadi fungsi dan bagaimana hubungan demokrasi desa dengan pemerintah ditentukan oleh partai politik itu sendiri (Panjaitan, 2015). Hal ini menimbulkan langkah yang efektif bagai pemerintah pusat maupun daerah untuk memainkan peran pada arena demokrasi desa, kepentingannya terbesarnya untuk mendapatkan simpati dari masyarakat desa. Hal ini dilakukan kerena adanya pandangan publik pada saat terjadi Covid-19 mengalami krisis kepercayaan. Krisis kepercayaan terjadi akibat peran-peran yang dimainkan pemerintah pusat maupun daerah yang kurang memperhatikan desa sebagai pemerintahan mandiri.

Desa sebagai organisasi kekuasaan tingkat lokal yang ada di Indonesia, yang secara mempunyai mempunyai wewenang tertentu karena merupakan bagian dari pemerintahan negara (Rudiadi \& Herawati, 2017). Desa sering dirumuskan sebagai suatu kesatuan masyarakat hukum yang berkuasa menyelenggarakan pemerintahan sendiri sebagai perwujudan pengakuan negara terhadap eksistensi desa. Keberadaan desa dalam konteks demokrasi, sebagai bagian dari masyarakat hukum desa mempunyai hak untuk mengurus kehidupan mereka secara mandiri (otonom), dan wewenang untuk mengurus dirinya itu sudah dimiliki sejak kesatuan masyarakat hukum itu ada tanpa diberikan oleh siapapun, sehingga dari sinilah mengapa desa disebut sebagai otonomi asli. Artinya hakikat desa merupakan pemerintahan asli yang otonom yang juga dapat memangku kepentingannya sendiri (Kusnadi, 2015). Di sisi lain adanya lahirnya Undang-Undang Nomor 6 Tahun 2014 tentang Desa dan adanya Covid-19, melahirkan perekonomian 
dan pembangunan desa sebagai pemerintahan yang tidak berdaya.

Pemilihan kepala desa sebagai salah satu bentuk demokrasi desa tidak dapat dilepaskan dari pengaruh pemerintah secara keseluruhan. Setingan-setingan kebijakan terhadap demokrasi desa dimulai dari tahap penjaringan bakal calon kepala desa, calon kepala desa, sampai pada pengendalian kepala desa ketika menang dalam Pemilihan kepala desa. Menjadikan kepala desa selalu dikendalikan dan tidak lagi memperhatikan pembangunan dan harapan-harapan masyarakat akan lahirnya pemimpin baru. Kepala desa ditempatkan sebagai petugas administrasi untuk melaksanakan bidang perekonomian dan pembangunan yang selalu mengharapkan bantuan pemerintah, tanpa melakukan penggalian terhadap potensi desa.

Harapan dari pemerintah dalam memberikan bantuan harus berubah total dengan adanya wabah dan menggiring desa sebagai peminta-minta saja terhadap kejaidan sperti sekarang. Covid-19 menjadikan perekonomian dan pembangunan desa mengalami proses pengkebirian yang dirasakan langsung oleh aparat desa tapi tentunya tidak untuk para petani yang sudah terbiasa mencari sendiri untuk mencukupi kebutuhan dan membangun keluargannya. Bantuan-bantuan pemerintah dalam bentuk ekonomi yang diberikan pada masyarakat desa, inilah yang menjadikan masyarakat desa tidak langi tangguh dan hanya mengharapkan belas kasihan pemerintah. Menjamurnya bantuan yang kurang terarah menajdikan desa pasca reformasi, menjadi salah satu alasan pembendar bagi pemerintah atas keberhasilan perekonomian tanpa memperhatikan dampak mental desa. Kondisi Covid-19 'memaksa' pemerintah untuk semakin gencar memberikan peringatan-peringatan akan bahaya Covid19, hasilnya masyarakat tidak menuruti pemerintah tanpa adanya imbalan yang berupa materi.
Secara politik hukum Undang-Undang Nomor 6 Tahun 2014 tentang Desa mencoba mengembalikan desa pada konsep otonomi asli melalui pengukuhan pengakuan atas kedudukan desa, pemberian kewenangan lokal berskala desa, pemberian status dan kedudukan perangkat desa yang bukan sebagai aparat pemerintah, serta pemberian pendanaan bagi desa melalui APBN dan dana perimbangan dalam bentuk alokasi dana desa. Dalam konteks implementasi, Undang-Undang Nomor 6 Tahun 2014 tentang Desa sendiri menghadapi tantangan terkait kesiapan desa dalam menjalankan kewenangankewenangannya, hingga persepsi pemerintah daerah terhadap kedudukan desa (Kusnadi, 2015). Kegagalan pemerintah daerah dan desa dalam mengelola tantangan tersebut akan mengakibatkan politik hukum pemerintahan desa sebagai pemangku otonomi asli tidak dapat terwujud. Terlebih lagi dengan berbagai bantuan terhadap desa oleh pemerintah sebetulnya sangat terlihat adanya pengkebirian terhadap pemerintahan desa, keterlibatannya memang tidak terlihat dalam pengkebirian demokrasi desa (Sarip, 2019).

Pernyataan Sri Mulyani sendiri tentang Desa pada dasarnya tidak dapat disamakan antara desa dengan kesatuan masyarakat hukum adat yang secara tegas dijamin UUD 1945: (Kementrian Keuangan Republik Indonesia, 2017) "Desa merupakan representasi dari kesatuan masyarakat hukum terkecil yang telah ada dan tumbuh berkembang seiring dengan sejarah kehidupan masyarakat Indonesia dan menjadi bagian yang tidak terpisahkan dari tatanan kehidupan bangsa Indonesia".

Bukti pengkebirian demokrasi desa sangat jelas dari pengertian desa itu sendiri, kemudian desa, praktinya desa hanya diberlakukan layaknya sebagai daerah arena uji coba bagi partai politik melalui sayapsayap politiknya. Adapun ukuran pengkebirian demokrasi oleh organisasi sayap partai politik dengan dapat dilihat dari beberapa segi: 
a) Pemilihan Kepala Desa yang luput dari perhatian pemerintah pusat justru dijadikan ajang bagi partai politik melalui sayap partai untuk mengendalikan desa;

b) Desa sebagai entitas yang sudah ada sebelum NKRI lahir pada tahun 1945, kurang mendapat perhatian dalam menata demokrasi dan pemerintah pusat hanya perkutat pada pembangunan fisik, akhinya sentuhan sayap politik memainkan desa sebagai ajang penghimpunan kekuatan untuk partai politik (Hanafi Arief, 2017);

c) Desa sekarang bukan merupakan bagian dari keragaman atau multikulturalisme Indonesia yang kemudian secara mudah diseragamkan oleh produk hukum yang berkenaan dengan desa, dalam hal ini pemerintah kurang memperhatikan desadesa atau dengan kata lain menyamakan antara desa dan kesatuan masyarakat hukum adat padahal desa sekarang tidak lagi dapat dikatakan sebagai kesatuan masyarakat hukum adat. Bahkan sekarang dengan lahirnya UndangUndang Desa tersebut membuat masyarakat desa semakin mengikuti gaya-gaya kota yang sedikit demi sedikit menghilangkan identitas asli masyarakatnya;

d) Desa sekarang sama seperti desa dalam lintas sejarah yakni menjadi arena eksploitasi, diperlakukan tidak adil, mulai dari era kerajaan, pemerintahan kolonial, hingga pemerintah NKRI. Cuma cara yang digunakan saat ini tidak sekeras masa lalu, yakni masuk melalui produk hukum.

e) Ketegasan perundang-undangan kurang menyentuk organisasi sayap partai politik, sehingga partai politik menggunakan sayap partainya secara leluasa.

Undang-Undang Nomor 6 Tahun 2014 tentang Desa hadir sebagai upaya pembaharuan desa. Undang-undang ini menjadi koreksi dan otokritik terhadap peraturan perundang-undangan tentang desa selama ini yang terkesan tidak serius dan memiliki komitmen besar terhadap standar pembangunan di desa. Mengenai pembaharuan desa, pembaharuan yang dimaksud tidak hanya sekedar melakukan revitalisasi desa atau merekonstruksi desa yang sudah rusak. Pembaharuan adalah proses transformasi sosial, atau perubahan yang sustain (berkelanjutan) yang direkayasa melalui perubahan paradigma, kebijakan publik, dan gerakan sosial dari masyarakat sipil (Timotius, 2018). Tapi tidak mempertimbangkan akan adanya tangan-tangan sebagaimana yang terjadi sekarang atas adanya Covid-19 yang melanda dunia.

\section{Bantuan Pemerintah Melahirkan Desa dan Masyarakat Serba Mengharap}

Desa merupakan entitas pemerintahan terendah dalam konteks Negara Kesatuan Republik Indonesia (NKRI), hal ini dapat dilihat dalam pasal $18 \mathrm{~B}$ ayat 2 Undangundang Dasar 1945 bahwa Negara mengakui kekhususan kesatuan-kesatuan masyarakat hukum adat yang tidak bertentangan dengan prinsip Negara Kesatuan Republik Indonesia. Dengan kata lain Negara mengakui eksistensi Desa sebagai bagian dari bentuk hirarki pemerintahan. Pasal 1 (1) Undang-Undang No. 6 tahun 2014 tentang Desa pengertian desa adalah; Desa adalah desa dan desa adat atau yang disebut dengan nama lain, selanjutnya disebut Desa, adalah kesatuan masyarakat hukum yang memiliki batas wilayah yang berwenang untuk mengatur dan mengurus urusan pemerintahan, kepentingan masyarakat setempat berdasarkan prakarsa masyarakat, hak asal usul, dan/atau hak tradisional yang diakui dan dihormati dalam sistem pemerintahan Negara Kesatuan Republik Indonesia.

Sedangkan kewenangan pemerintah desa dapat dilihat pada Pasal 18 dan Pasal 19 Undang-udang No. 6 Tahun 2014 tentang 
Desa. Pasal 18 Undang undang No.6 Tahun 2014 berbunyi "Kewenangan desa meliputi kewenangan di bidang penyelenggaraan pemerintahan desa, pelaksanaan pembangunan desa, pembinaan kemasyarakatan desa, dan pemberdayaan masyarakat desa berdasarkan prakarsa masyarakat, hak asal usul, dan adat istiadat desa". Gerakan sayap politik di desa merupakan problematika yang dihadapi oleh partai-partai politik termasuk pengaturannya. Pemilihan kepala desa pada dasarnya sebagai proses politik yang langsung menyentuh kepentingan politik paling mendasar dari masyarakat, politik lokal diyakini lebih memengaruhi kehidupan setiap hari dibanding politik nasional. Hal ini seperti ditegaskan oleh Terry Christensen, menegaskan bahwa secara definisi, politik lokal menekankan pada pengambilan keputusan, pengambilan suara, dan kebijakan publik yang dilakukan di tingkat lokal ketika seorang individu atau sekelompok kecil masyarakat dapat terlibat dan memengaruhi secara langsung.

Sudut politik desa sebagai kekuasaan dimaksudkan untuk mencegah penumpukan kekuasaan pada satu pihak saja yang pada akhirnya dapat menimbulkan tirani. Penyelenggara pemerintahan desa dianggap sebagai tindakan pendemokrasian untuk menarik rakyat ikut serta dalam pemerintahan dan melatih diri dalam mempergunakan hak-hak demokrasi. Namun yang terjadi justru masuknya organsisasi sayap politik sebagai kaum penekan menjadi permasalahan tersendiri untuk membangun demokrasi desa. Suatu gerakan kedap suara yang dilakukan oleh organisasi saya politik tidak terlepas dari kelonggaran perundang-undangannya sendiri.

Sementara perbincangan tentang otonomi desa seringkali dikaitkan dengan otonomi daerah dan bahkan seringkali disama-artikan. Padahal istilah otonomi daerah dan otonomi desa berbeda satu sama lain. Otonomi desa tidak dapat dipahami sebagai pemberian atau konsekuensi dari adanya otonomi daerah. Otonomi desa telah sejak lama. Bahkan, kalau ditelusuri dari sejarah keberadaan desa-desa di Indonesia, maka akan terlihat jelas bahwa pada dasarnya otonomi desa lebih dulu ada daripada otonomi daerah.

Desa sebagai kesatuan masyarakat hukum juga memiliki tradisi dalam menyeleksi pemimpinnya. Tradisi tersebut dari waktu ke waktu telah mengalami evolusi sejalan dengan perkembangan dan pertumbuhan desa itu sendiri. Saat ini untuk melakukan seleksi pemimpin desa dilakukan melalui pemilihan kepala desa. Pemilihan kepala desa meskipun dalam bentuk sederhana adalah sebuah sistem politik, yang merupakan bagian dari sistem politik lain yang lebih besar dan kompleks.

Desa dalam pandangan politik adalah sebuah masyarakat demokrasi, sebuah masyarakat yang mendasarkan diri pada kedaulatan rakyat (Sholikah, 2014). Demokrasi desa itulah yang dianggap sebagai demokrasi "asli" yang bisa dijadikan orientasi dalam pengembangan demokrasi modern di tingkat nasional, dengan ciri-ciri seperti musyawarah, rembug desa, dan pemilihan kepala desa oleh rakyat di desa, dari calon-calon yang mereka ajukan sendiri.

Desa sebagai laboratorium hukum ketatanegaraan mungkin kedengarannya tidak terlalu baik, fakta akan membuktikan bahwa desa pantas dijadikan sebagai laboratorium hukum ketatanegaraan Indonesia. Mulai dari cara hidup yang baik, sopan santun, dan yang terakhir tentunya berkenaan dengan politik uang selalu menjadi fenomena nasional dan melupakan akan keberadaan laboartoriumnya itu sendiri. Dilihat dari persefektif sosial, hukum merupakan salah satu dari subsistem sosial yang juga memiliki ketergantungan dengan sub-sistem sosial yang lain. Begitu juga dengan ketatanegaraan Indonesia yang membagi wilayah pemerintahan ke dalam tiga bagian yakni pemerintah pusat, pemerintah daerah, dan pemerintah desa. Ketiganya tidak dapat 
dipisahkan satu sama lainnya dan merupakan satu kesatuan yang utuh, justru desa dalam hal ini sebagai dasar pembentukan negara atau sebagai laboratorium negara Indonesia.

Ada beberapa indikator yang digunakan untuk melihat terjadinya peningkatan kesadaran warga masyarakat, pengurus organisasi, dan aparat pemerintah desa dalam perencanaan, penganggaran, dan evaluasi hasil pembangunan desa (Susetiawan et al., 2018). Beberapa indikator tersebut sebagai berikut: (1) Terbangunnya komitmen warga masyarakat untuk berani menyampaikan ide/usulan pada forum publik/musyawarah desa, khususnya dalam hal perencanaan, penganggaran, dan evaluasi hasil pembangunan;

Terbangunnya komitmen organisasi warga untuk mulai mempraktikkan dan mendiskusikan tata cara perencanaan, penganggaran, dan evaluasi hasil pembangunan dengan prosedur yang baik; (3) Terbangunnya komitmen aparat pemerintahan desa untuk terbuka, responsif, dan akuntabel dalam perencanaan, penganggaran, dan evaluasi hasil pembangunan desa.

Apa yang terjadi pada desa dan masyarakat desa yang telah melahirkan mental pengharap akibat kebijakan yang kurang tepat, pada akhirnya nilai-nilai yang diharapkan dalam demokrasi Pancasila mengalami sedikit kegagalan (Sarip, 2018). Kegagalan demokrasi desa, maka pemerintah harus segera berbenah atas kebijakan-kebijakan yang telah melahirkan masyarakat materalisti. Tujuan adanya negara Indonesia untuk memperjuangkan cita-citanya dalam kehidupan bermasyarakat, berbangsa, dan bernegara yang diwujudkan secara konstitusional. Perlu diterangkan bahwa negara setelah wabah berakhir, pemerintah segera melakukan peninjuan-peninjuan agar kebijakan-kebijakan pemerintah tidak mengarah pada mental yang justru membuat masyarakat sebagai peminta-minta.
Orientasi ini merupakan kebijkankebijkan antara pemerintah agar dapat menumbuhkan suatu identitas desa yang memiliki mental kuat. Demi terwujudnya suatu demokrasi desa di bidang perekonomian dan pembangunan, pemerintah jangan membentuk mentalmental desa yang melahirkan pemintaminta. Pemerintah harus berpartisipasi aktif bukan hanya penyaluran materi saja, dengan mendudukkan kader-kadernya menjadi pejabat pemerintah sbagai wakil rakyat, sehingga dapat turut serta dalam mengambil dan menentukan keputusan politikberupa kebijakan sesuai dengan kepentingan masyarakat. Masyarakat desa pada dasarnya tidak memiliki mental peminta-minta, maka pemerintah sudah selanyaknya dalam mengeluarkan kebijakan-kebijakan harus menghindarkan kebijakan yang mengarah pada keadaan tersebut.

\section{KESIMPULAN}

Covid-19 telah merubah perekonomian dunia, termasuk Indonesia dibuktikan adanya pengalihan-pengalihan anggaran dalam rangka penanganya, termasuk di desa-desa. Penamanaa 2019-nCoV disematkan World Health Organization (WHO) untuk coronavirus disease that was discoverd in 2019 pada tanggal 11 Februari 2020, dengan sebutan Covid-19. Memiliki dampak yang sangat luar biasa di seluruh dunia tidak ketinggalan juga dengan desadesa yang ada di Indonesia. Desa-sesa terpengaruh terutama dalam bidang ekonomi dan pembangunan yang selama ini banyak mengandalkan bantuan dari pemerintah. Desa sebagai organisasi kekuasaan tingkat lokal yang ada di Indonesia, yang secara mempunyai mempunyai wewenang tertentu karena merupakan bagian dari pemerintahan negara. Desa sering dirumuskan sebagai suatu kesatuan masyarakat hukum yang berkuasa menyelenggarakan pemerintahan sendiri sebagai perwujudan pengakuan negara terhadap eksistensi desa. Keberadaan desa dalam konteks demokrasi, sebagai 
bagian dari masyarakat hukum desa mempunyai hak untuk mengurus kehidupan mereka secara mandiri (otonom), dan wewenang untuk mengurus dirinya itu sudah dimiliki sejak kesatuan masyarakat hukum itu ada tanpa diberikan oleh siapapun, sehingga dari sinilah mengapa desa disebut sebagai otonomi asli desa. Demi terwujudnya suatu demokrasi desa di bidang perekonomian dan pembangunan, pemerintah jangan membentuk mentalmental desa yang melahirkan pemintaminta.

\section{DAFTAR PUSTAKA}

Amanulloh, N. (2015). Demokratisasi Desa : Kementerian Desa, Pembangunan Daerah Tertinggal, Dan Transmigrasi Republik Indonesia, 1-47.

Astutiningsih, S. E., \& Sari, C. M. (2017). Pemberdayaan Kelompok Agroindustri Dalam Upaya Mempercepat Pertumbuhan Ekonomi Jawa Timur. Jurnal Ilmu Ekonomi Terapan, 2(1), 19.

https://doi.org/10.20473/jiet.v2i1.5500

Haerisma, A. S. (2019). Konsepsi Pemikiran Dasar Ekonomi Islam, Ekonomi Pancasila Dan Ekonomi Kerakyatan Untuk Kesejahteraan Masyarakat. AlMustashfa: Jurnal Penelitian Hukum Ekonomi, 4(2), 187-199.

Hanafi Arief. (2017). Rekonstruksi Hukum Tentang Hukuman Kebiri Bagi Pelaku Tindak Pidana Pelecehan Seksual. Jurnal Khazanah: Jurnal Studi Islam Dan Humaniora, 14(1), 110-133. https://doi.org/10.1017/CBO97811074 15324.004

Hanoatubun, S. (2020). Dampak Covid-19 Terhadap Perekonomian Indonesia. EdusPsyCoun Journal, Juranal of Education, Psyhology and Counseling, 2(1), 146-153.

Hidayat, E., Prasetyo, B., \& Yuwana, S. (2019). Runtuhnya Politik Oligarki dalam Pemilihan Kepala Desa: Kekalahan Incumbent pada Pilkades Tanjung Kabupaten Kediri. Jurnal
Politik, 4(1), 53. https://doi.org/10.7454/jp.v4i1.193

Hsb, A. M. (2017). Kegentingan yang Memaksa dalam Pembentukan Peraturan Pemerintah Pengganti Undang-Undang. Jurnal Legislasi Indonesia, 14(1), 109-122.

Kementrian Keuangan Republik Indonesia. (2017). Buku Pintar Dana Desa. Buku Pintar Dana Desa, 113. https://www.kemenkeu.go.id/media/67 49/buku-pintar-dana-desa.pdf

Kushandajani, \& Kushandajani. (2017). Implikasi Uu No. 6 Tahun 2014 Tentang Desa Terhadap Penyelenggaraan Pemerintahan Desa. Implikasi Uu No. 6 Tahun 2014 Tentang Desa Terhadap Penyelenggaraan Pemerintahan Desa, 2(1), 53-64. https://doi.org/10.14710/jiip.v2i1.1635

Kusnadi, A. (2015). Perkembangan Politik Hukum Pemerintahan Desa Menurut Undang-Undang Nomor 32 Tahun 2004 tentang Pemerintahan Daerah dan Undang-Undang Nomor 6 Tahun 2014 tentang Desa. PADJADJARAN Jurnal Ilmu Hukum (Journal of Law), 2(3), 564-580.

https://doi.org/10.22304/pjih.v2n3.a8

Lisbet. (2020). Penyebaran covid-19 dan Respons Internasional. Info Singkat, XII(5), 7-12.

Panjaitan, M. J. (2015). Fungsi dan hubungan Organisasi Sayap Partai Politik di Indonesia. 3(2), 54-67. http://repositorio.unan.edu.ni/2986/1/5 624.pdf

Purnamasari, G. C. (2019). Pergeseran Fungsi Dan Kedudukan Badan Permusyawaratan Desa Menurut Undang-Undang Nomor 6 Tahun 2014 Tentang Desa (Studi Bpd Desa Kunjang). Refleksi Hukum: Jurnal Ilmu Hukum, 3(2), 161-174. https://doi.org/10.24246/jrh.2019.v3.i2. p161-174

Puspasari, R. (2020). Pemerintah Waspada Dampak Pandemi Covid-19 Terhadap 
Ekonomi Indonesia. Kementerian Keuangan Republik Indonesia, April, 17-21.

https://www.kemenkeu.go.id/apbnkita/

Rudiadi, \& Herawati, R. (2017). Pemilihan

Kepala Desa Serentak Dalam

Persefektif Otonomi Desa (Studi Kasus

Pelaksanaan Pemilihan Kepala Desa

Serentak Tahun 2016 di Kabupaten Rokan Hilir, Provinsi Riau). Law Reform, 13(1), 132. https://doi.org/10.14710/lr.v13i1.15956

Sarip, S. (2018a). Pemikiran the King Can

Do Not Wrong dalam Politik Hukum

Ketatanegaraan Indonesia. Kanun Jurnal Ilmu Hukum, 20(2), 315-336. https://doi.org/10.24815/kanun.v20i2.1 0157

Sarip, S. (2018b). The Manifestation of Indonesian Democracy; Between Pancasila State of Law and Islamic Nomocracy. Jurnal Hukum Novelty, 9(2), 192. https://doi.org/10.26555/novelty.v9i2.a 11517

Sarip, S. (2019). Produk Hukum Pengkebirian Pemerintahan Desa. Jurnal Hukum \& Pembangunan, 49(1), 60.

https://doi.org/10.21143/jhp.vol49.no1. 1910

Sarip, S., \& Wahid, A. (2018). Kemajemukan Visi Negara Hukum Pancasila Dalam Misi Hukum Negara Indonesia. Refleksi Hukum: Jurnal Ilmu Hukum, 2(2), 109-124. https://doi.org/10.24246/jrh.2018.v2.i2. p109-124

Sholikah, A. (2014). Perilaku Politik Masyarakat Dalam Pemilihan Kepala Desa (Studi Pada Masyarakat Desa Kutasari Kecamatan Cipari Kabupaten Cilacap). Komunika, 8(1), 79-97.

Susetiawan, S., Mulyono, D., \& Roniardian, M. Y. (2018). Penguatan Peran Warga Masyarakat Dalam Perencanaan, Penganggaran, dan Evaluasi Hasil Pembangunan Desa. Jurnal Pengabdian Kepada Masyarakat, 4(1),
109.

https://doi.org/10.22146/jpkm.27512

Timotius, R. (2018). Revitalisasi Desa Dalam Konstelasi Desentralisasi Menurut Undang-Undang Nomor 6 Tahun 2014 Tentang Desa. Jurnal Hukum \& Pembangunan, 48(2), 323. https://doi.org/10.21143/jhp.vol48.no2. 1666

Wulandari, L. (2017). Strategi Perencanaan Pembangunan Desa di Desa Sukaresik Kecamatan Sidamulih Kabupaten Pangandaran. MODERAT: Jurnal Ilmiah Ilmu Pemerintahan, 3(3), 5566.

https://doi.org/http://dx.doi.org/10.251 47/moderat.v3i3.752

Yuliana. (2020). Corona virus diseases (Covid -19); Sebuah tinjauan literatur. Wellness and Healthy Magazine, 2(1), 187-192.

https://wellness.journalpress.id/wellnes s/article/view/v1i218wh

Yuningsih, N. Y., \& Subekti, V. S. (2016). Demokrasi dalam Pemilihan Kepala Desa? Studi Kasus Desa Dengan Tipologi Tradisional, Transisional, dan Modern di Provinsi Jawa Barat Tahun 2008-2013. Jurnal Politik, 1(2). https://doi.org/10.7454/jp.v1i2.21 